\title{
Characterization of fruits of varieties of mango (Mangifera indica) conserved in Peru
}

\author{
Lady Laura Tuisima Coral $^{1} \&$ Hector Alonso Escobar-Garcia ${ }^{2}$
}

\begin{abstract}
The department of Piura is the main mango producer in Peru accounting for $66.7 \%$ of the national crop. The objective of the study was to characterize the fruits of forty varieties of mango preserved since 1969 in northwestern Peru. The fruits were harvested at the El Chira Agrarian Experimental Station, Department of Piura from December 2019 to January 2020. Thirteen quantitative fruit variables were evaluated: width, thickness, length, weight, seed width, seed thickness, seed length, percentage of seed, percentage of fresh skin, percentage of pulp, texture, ${ }^{\circ}$ Brix, and pulp / seed ratios. The varieties with the highest percentage of pulp were Tommy Atkins, Haden $\mathrm{x}$ carabao 1, Irwin, and Jaffra, the latter was also the variety with the highest pulp / seed ratio (17.0). The varieties with the highest ${ }^{\circ}$ Brix were Blacman $\left(21.3^{\circ}\right.$ Brix $)$ and Julie $\left(22.0^{\circ}\right.$ Brix $)$. Knowledge of the fruit characteristics is essential for proper selection and use by the industry, especially those with a higher pulp weight to obtaining higher yields in processing.
\end{abstract}

Index terms: Anacardiaceae, pulp percentage, seed percentage, Brix degrees.

\section{Caracterização de frutos de variedades de manga (Mangifera indica) conservadas no Peru}

Corresponding author: hescobarg@unp.edu.pe

Received: September 16, 2019 Accepted: March 05, 2021

Copyright: All the contents of this journal, except where otherwise noted, is licensed under a Creative Commons Attribution License.
Resumo - O Departamento de Piura é o principal produtor de manga do Peru, representando 66,7\% da safra nacional. O objetivo do estudo foi caracterizar os frutos de quarenta variedades de manga, preservadas desde 1969, no noroeste do Peru. Os frutos foram colhidos na Estação Experimental Agrária de El Chira, Departamento de Piura, de dezembro de 2019 a janeiro de 2020. Foram avaliadas treze variáveis quantitativas dos frutos: largura, espessura, comprimento, peso, largura da semente, espessura da semente, comprimento da semente, porcentagem de semente, porcentagem de casca fresca, porcentagem de polpa, textura, ${ }^{\circ}$ Brix e relação polpa / semente. As variedades com maior percentual de polpa foram Tommy Atkins, Haden x carabao 1, Irwin e Jaffra, sendo esta última, também, a variedade com maior relação polpa / semente $(17,0)$. As variedades com maior ${ }^{\circ}$ Brix foram Blacman ( $21,3^{\circ}$ Brix $)$ e Julie $\left(22,0^{\circ}\right.$ Brix). O conhecimento das características dos frutos é essencial para a correta seleção e o aproveitamento pela indústria, principalmente aquelas com maior peso de polpa para obtenção de maiores rendimentos no processamento.

Termos para indexação: Anacardiaceae, porcentagem de polpa, porcentagem de sementes, graus 
Brix.

\section{Introduction}

Mango belongs to the genus Mangifera, which consists of around 30 species of tropical fruit trees in the Anacardiaceae family, it has been cultivated in India for more than 4000 years, and mango is native to Southeast Asia (SHAH et al., 2010). The diversity of mango fruits is enormous, and each one has its own unique flavour and characteristics. Beginning in the $16^{\text {th }}$ century, mango fruits were gradually distributed throughout the world, reaching the Americas in the $18^{\text {th }}$ century (CRANE et al., 2017).

Brazil was the first country in America to cultivate this plant, first introduced by the Portuguese to Rio de Janeiro in the $16^{\text {th }}$ century, expanding throughout the country. Currently, Brazil stands out as the seventh mango producer and most of the production is concentrated in the states of Bahia (23\%), Pernambuco (23\%), and São Paulo (18\%) (MAIA et al., 2016; IBGE, 2016).

In Peru, only the yellow mango variety was registered as Criollo de Chulucanas, and it was introduced in 1810 by the Spaniards. In 1969, 44 cultivars were introduced from Florida (USA) and planted at the El Chira Agricultural Experiment Station in northwestern Peru. Since then, mangoes have been grown in 22 of Peru's 24 Departments with an approximate area of 30,817 hectares. The Departments of Piura (66.7\%), and Lambayeque (14.6\%) together contribute approximately $82 \%$ of Peru's total mango crop (SIEA 2014-2019).

In 2020, Peru exported 242,879,787 $\mathrm{kg}$ of fresh mango with a FOB price of 284,101,570 USD, with the Netherlands and the United States as the main importing countries, receiving $66 \%$ of exports (AGRODATAPERU 2020). The most popular commercial varieties are Kent, Haden, Edward, and Tommy Atkins, known as improved varieties. There are also non-grafted varieties, such as the Criollo de Chulucanas, the Rosado mango, or the Chato de Ica variety, which are planted in the Department of Ica, Peru (MINAGRI, 2014). Mango fruit is low in calories and very rich in acids, vitamin $C$, vitamin B5, and vitamin A, making it an antioxidant fruit, providing the body with a defensive power against cell degradation (LEDESMA, 2018).

Due to the importance of this fruit, the Banco Agrario (2007) of Peru characterized the commercial varieties of mango according to their color as red, green, and yellow. Within the red group are the Kent variety, the most exported from Peru, large in size (500 to $800 \mathrm{~g}$ ), it has a yellow-orange epicarp with reddish color when ripe, oval orbicular shape, pleasant flavour, juicy, with low fibrosity and high sugar content, it is also a late variety. The Haden variety, of medium to large size (380 to 700 g) and yellow epicarp with reddish or totally red, is oval in shape with firm flesh, pleasant flavour, and is an early variety. The Tommy Atkins variety, large in size (600 g), is oblong, oval in shape, resistant to mechanical damage and it has a longer shelf life. However, it does not have the best flavour and aroma characteristics. It is also an early variety and more common in the markets.

Forty varieties are currently conserved in the mango germplasm bank located in the Department of Piura, they receive adequate management of irrigation, fertilization, and pruning activities, which allows a good yield and the conservation of the germplasm.

Some morphological differences between varieties are notorious, however, there is no report of their characterization. The objective of this research was to characterize forty mango varieties using fruit quantitative variables in order to know the existing variability of the collection, and it can contribute to making appropriate decisions for the production, management, and conservation of the mango collection.

\section{Materials and Methods}

\section{Location of the germplasm bank}

In 1969, four plants of 44 varieties of mango from Florida (USA) were installed, completing a total of 176 trees, of which 40 varieties are currently conserved with a total of 125 living trees. The germplasm bank was established in the district of Tambogrande, Department of Piura, Peru, located at 4'52' 55.64'S, and 80¹9'12.19' 'W and $82 \mathrm{~m}$ altitude (Figure 1). The climate is classified as $B W h$ type, which means tropical and subtropical desert climate.

\section{Sample collection and evaluation of quantitative} variables

Within the period December 2019 - January 2020, 10 ripe fruits were randomly collected for each mango variety; we evaluated the weight, width, thickness, and length of the fruit and the seed, fresh weight of the skin, weight, and texture of the pulp and ${ }^{\circ}$ Brix. Knowing the weights of pulp, seed, and fresh skin, the percentages of each variable with respect to the total weight of the fruit was calculated, and we obtained the pulp/seed ratio, getting a total of 13 quantitative variables of the fruit. Values related to weight were obtained using a weight scale (Camry, China), the dimensional variables were recorded using a digital vernier (Stainles shardened, China). The texture was evaluated with a penetrometer (Wagner, Italy), and to evaluate ${ }^{\circ}$ Brix was used a digital handheld refractometer (Boeco, Germany). 

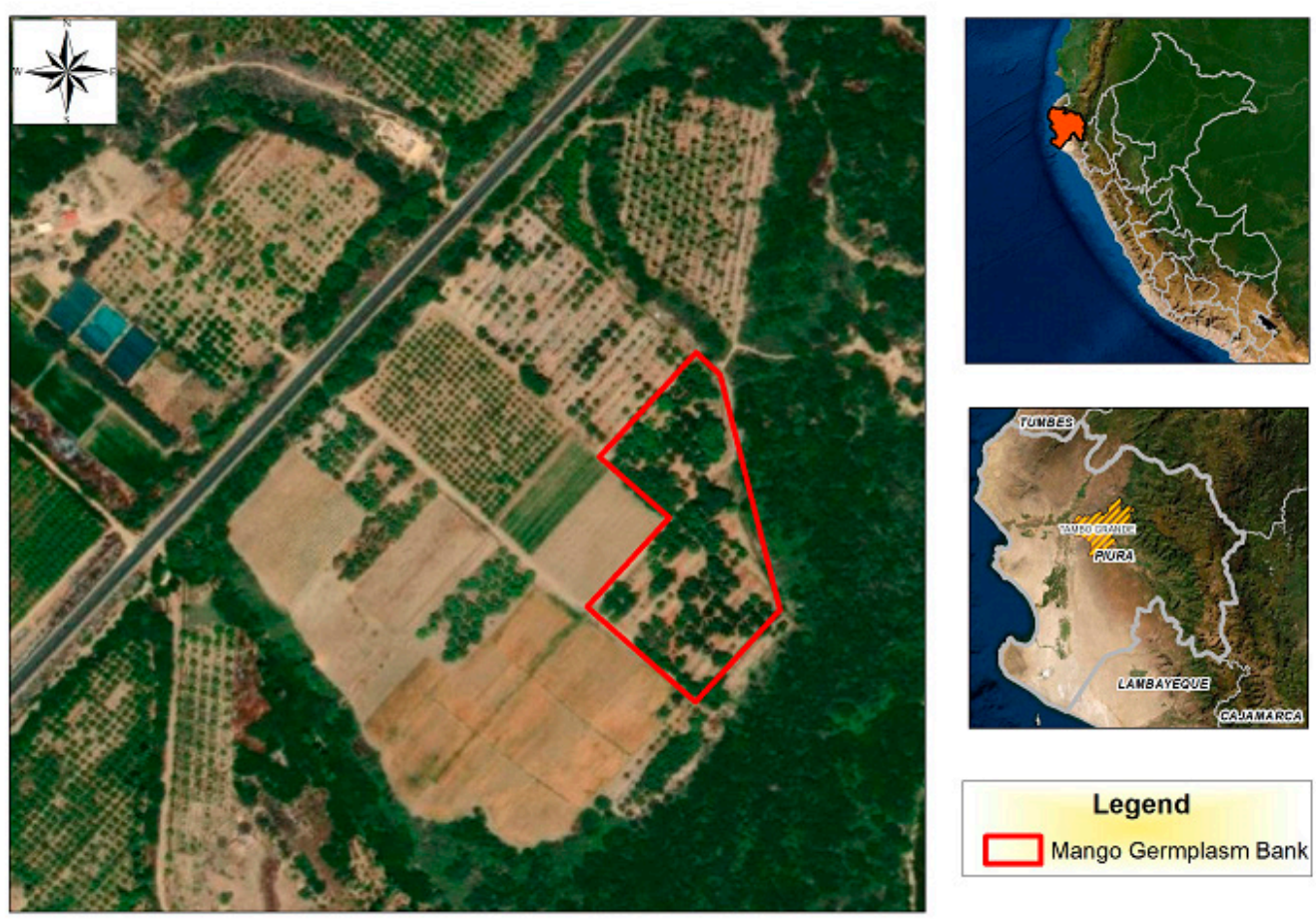

Figure 1. The geographical location of the mango germplasm bank, established in the district of Tambogrande, Province of Piura, Peru.

\section{Data analysis}

The experimental design used was completely randomized with 10 replications. Quantitative variables were standardized to whole numbers to one decimal place. Simple descriptive statistics were obtained for all variables. To determine the similarity between mango varieties, cluster analysis (CA) was performed using Ward's grouping method. This method was considered because it seems to be much more discriminative in the determination of grouping levels, and widely used for the analysis of quantitative variables. Subsequently, to determine the existence or not of statistical differences between the groups formed, a one-way analysis of variance (ANOVA) was performed and Tukey's test was used ( $\mathrm{p} \leq$ 0.05). A multiple Pearson correlation analysis was added. Finally, a principal component analysis (PCA) of the thirteen quantitative variables under study was performed using StatGraphicsV. 19 software (StatGraphics 2009). A significance level of $5 \%$ was used in all statistical analyses.

\section{Results and Discussion}

\section{Weight and dimensions of fruit and seed}

We obtained the averages, standard deviation, and coefficient of variation of quantitative fruit variables of the 40 mango varieties evaluated. The lightest mango varieties according to the average fruit weight and length were:
Ono (155.0 g - $86.0 \mathrm{~mm})$, Saigon (167.0 g - $92.0 \mathrm{~mm})$ and Chirimollo (174.0 g- $75.0 \mathrm{~mm}$ ). While the heaviest mango varieties were Sprinffels $(670.0 \mathrm{~g}-152.0 \mathrm{~mm})$, Haden x Carabao 2 (681.0 g - 137.0 mm), and Jaffra (688.0 $\mathrm{g}-121.0 \mathrm{~mm})$. Moreover, Golex recorded a higher weight compared to the rest of the varieties $(879.0 \mathrm{~g})$ (Table 1$)$.

Fruits weight of the export varieties were Kent (625.0 g), Edward (599.0 g), Tommy Atkins (510.0 g), and Haden (322.0 g). Crane et al. (2017) and Ledesma (2018) reported some fruit characteristics of 37 and 109 mango varieties, respectively, which grow in Florida. Of all of them only nine varieties are included among the varieties evaluated in this work (Edward, Fairchild, Glenn, Haden, Julie, Kent, Palmer, Sensation, and Tommy Atkins). This demonstrates the extensive diversity of mango varieties.

Of the nine varieties, the fruit weight of Haden (322.0 g) and Palmer (187.0 g) were lower than those reported by Crane et al (2017) with an average of 566.7 $\mathrm{g}$ for both varieties, meanwhile Ledesma (2018) recorded averages of $600.0 \mathrm{~g}$ for those varieties. In addition, Edward, Haden, Kent, and Tommy Atkins stand out as commercial varieties. All of them, with the exception of Haden, are varieties with an average fruit weight greater than $500.0 \mathrm{~g}$ and considered of large size.

Jaffra and Golex were the varieties with the lowest seed proportion $(4.8 \%$ and $5.5 \%$, respectively), while Ono (15.8\%), Palmer (16.2\%), and Saigon (18.3\%) were the varieties with the highest seed proportion. Dried mango seeds contain $15 \%$ tannin which could be used as an astringent in cases of diarrhea, dysentery, and urethritis. Previous studies revealed that mango seeds are free of toxic substances and appear to be a safe source of antioxidants (SOWMIYA et al., 2009). On the 
other hand, the variables with the highest coefficient of variation were fruit weight $(\mathrm{CV}=49.7 \%)$, seed length $(\mathrm{CV}=24.8 \%)$, and fruit length $(\mathrm{CV}=23.1 \%)$, in contrast to seed thickness $(\mathrm{CV}=10.5 \%)$. In this context, the fruit is sold in the European market according to quality types based on the commercial characteristics of size and color. In addition, Rodríguez-Pleguezuelo et al. (2012), indicate that consumers more appreciate medium-sized fruits.

\section{Proportion and texture of skin and pulp}

Tommy Atkins had a lower proportion of fruit skin $(7.5 \%)$. This variety also presented a higher percentage of pulp (84.8\%), moreover, this percentage is comparable with the studies reported by Siller-Cepeda et al. (2009), Rodriguez-Pleguezuelo et al. (2012), and Carneiro et al. (2018) with $76 \%, 81.9 \%$, and $66.4 \%$, respectively.

Of the forty (40) mango varieties, fourteen (14) recorded more than $80 \%$ pulp percentage (Table 1), so they could be considered for obtaining mango pulp and also those can be processed in the manufacture of sweets, juices, or ice cream (Pitchaon, 2011). On the other hand, the texture variable is associated with the stage of ripening, for as the fruit reaches the highest stage of ripening the texture get reduced. For the acceptable eating quality of mango fruits in relation to their texture, they should present values between 1.75 to $2.0 \mathrm{~kg} / \mathrm{cm}^{2}$ according to Mitcham and McDonald (1992).

Fruit texture ranged from $1.0 \mathrm{~kg} / \mathrm{cm}^{2}$ to $5.7 \mathrm{~kg} /$ $\mathrm{cm}^{2}$. At the time of evaluation, eight (8) varieties recorded texture values below those of acceptable quality according to Mitcham and McDonald (1992), this parameter should be considered when deciding the appropriate time to harvest. In contrast, thirteen (13) varieties recorded values greater than $2.8 \mathrm{~kg} / \mathrm{cm}^{2}$ (Table 1), all of them also considered of late maturing. It was also observed that the Erlivety, Philips, and Sensation varieties are characterized by hard flesh, while Tolbert variety has hard skin and soft flesh. The maximum texture value was recorded for the Haden variety at $5.7 \mathrm{~kg} / \mathrm{cm}^{2}$ evaluated before it reaches the optimum ripening stage.

Brix degrees $\left({ }^{\circ} \mathrm{Brix}\right)$ and pulp/seed ratio (pulp/se) The ${ }^{\circ}$ Brix range was from 15.0 to 22.0. The varieties with the lowest ${ }^{\circ}$ Brix value were: Kevis \& Patil, Golex, Haden, Irwin, and Tolbert, these last two varieties could be considered important for the consumption of people with insulin resistance or diabetes, due to their low level of total soluble solids. In this context, Shah et al. (2010) indicate that mango has antidiabetic, antioxidant, antiviral, cardiotonic, gastroprotective, and anti-inflammatory properties. In contrast, the varieties with the highest ${ }^{\circ} \mathrm{Brix}$ were Blacman (21.3 ${ }^{\circ}$ Brix) and Julie (22.0 ${ }^{\circ}$ Brix).
Corresponding to the pulp/seed ratio, RodriguezPleguezuelo et al. (2012) stated that as much higher is the pulp/seed ratio, the mango variety can be considered commercially valuable, in that context the Jaffra variety excelled with respect to the pulp/seed ratio (17.4) with $16.3{ }^{\circ} \mathrm{Brix}$, so it could also be considered as a variety of commercial importance. However, it has been observed that the shelf life of this variety is short, so its scope would be in a national context. Moreover, ${ }^{\circ}$ Brix and pulp/seed ratios of the export varieties were: Kent $\left(18.8^{\circ} \mathrm{Brix}\right.$ and $11.6 \mathrm{pulp} / \mathrm{seed}$ ratio), Edward (18.0 ${ }^{\circ} \mathrm{Brix}$ and $12.5 \mathrm{pulp} /$ seed ratio), Tommy Atkins $\left(15.8^{\circ} \mathrm{Brix}\right.$ and $10.9 \mathrm{pulp} / \mathrm{seed}$ ratio) and Haden $\left(15.0^{\circ} \mathrm{Brix}\right.$ and $6.6 \mathrm{pulp} / \mathrm{seed}$ ratio). The ${ }^{\circ}$ Brix results for the commercial varieties in this research were superior to those reported by Rodríguez-Pleguezuelo et al. (2012) in European Mediterranean conditions, but Fernández et al. (2001) in an Argentine subtropical climate, recorded $15.2^{\circ}$ Brix for Haden, $14.0^{\circ}$ Brix for Tommy Atkins and $20.0^{\circ}$ Brix for Kent.

Multiple correlation of quantitative variables of mango fruit

Correlation analysis indicated that the quantitative variables of fruit weight, seed percentage and flesh percentage, and fruit length were positively and highly significantly related to each other (Table 2). Therefore, the larger the fruit size, the higher the seed and pulp percentage, and greater the fruit length. In order to obtain more pulp and less seed percentage, it would be important to initiate research on crosses or in vitro trials to create hybrids with a higher percentage of pulp and small seeds. In addition, fruit width is positively correlated with 10 of the variables with the exception of the variable ${ }^{\circ} \mathrm{Brix}$ which has a negative correlation $(\mathrm{r}=-0.39 ; \mathrm{p} \leq 0.05)$, which is also inherent to the variety. Fruit texture is about $43 \%$ related to skin fresh weight, in this regard, thirteen varieties recorded between $15.2 \%$ and $21.0 \%$ fresh skin weight. In contrast, there is a negative correlation between fruit weight, flesh percentage, and texture concerning to ${ }^{\circ}$ Brix $(r=-0.36 ; p \leq 0.05)$, i.e., the higher the fruit weight, flesh percentage, and texture, the lower the value of ${ }^{\circ}$ Brix or total soluble solids. ${ }^{\circ}$ Brix is associated with the ripening period; to investigate this aspect in promising varieties is required. 
Table 1. Averages of fruit width (FW), fruit thickness (FT), fruit length (FL), fruit weight (Fw), seed width (SW), seed thickness (ST), seed length (SL), seed percentage ( $\% \mathrm{Se})$, fresh skin percentage $(\% \mathrm{PFs})$, pulp percentage $(\%$ $\mathrm{Pp})$, texture (Text), Brix degree ( $\left.{ }^{\circ} \mathrm{Brix}\right)$ and pulp/seed ratio (Pulp/se) of 40 mango varieties.

\begin{tabular}{|c|c|c|c|c|c|c|c|c|c|c|c|c|c|}
\hline VARIETIES & $\begin{array}{c}\mathrm{FW} \\
(\mathrm{mm})\end{array}$ & $\begin{array}{c}\text { FT } \\
(\mathrm{mm})\end{array}$ & $\begin{array}{c}\text { FL } \\
(\mathrm{mm})\end{array}$ & $\begin{array}{l}\text { Fw } \\
(\mathrm{g})\end{array}$ & $\begin{array}{l}\text { SW } \\
(\mathrm{mm})\end{array}$ & $\begin{array}{c}\text { ST } \\
(\mathrm{mm})\end{array}$ & $\begin{array}{c}\text { SL } \\
(\mathrm{mm})\end{array}$ & $\begin{array}{l}\% \\
\mathrm{Se} \\
\end{array}$ & $\begin{array}{c}\% \\
\text { PFs } \\
\end{array}$ & $\begin{array}{l}\% \\
\mathrm{Pp} \\
\end{array}$ & $\begin{array}{c}\text { Text } \\
\left(\mathrm{kg} / \mathrm{cm}^{2}\right)\end{array}$ & ${ }^{\circ}$ Brix & $\begin{array}{l}\text { Pulp/ } \\
\text { se }\end{array}$ \\
\hline 1 AROEMANIS & 65.0 & 54.0 & 110.0 & 210.0 & 30.0 & 16.0 & 91.0 & 10.0 & 15.2 & 74.8 & 2.0 & 19.0 & 7.5 \\
\hline 2 AMINI & 4.5 & 63.5 & 85.0 & 226.0 & 33.0 & 23.5 & 61.5 & 10.6 & 14.4 & 75.0 & - & 18.5 & 7.4 \\
\hline 3 BLACMAN & 76.5 & 59.5 & 89.0 & 215.0 & 43.0 & 17.0 & 67.0 & 9.5 & 12.6 & 77.9 & 2.3 & 21.3 & 8.4 \\
\hline 4 BOMBAY & 73.0 & 64.5 & 76.0 & 209.0 & 40.5 & 18.5 & 60.5 & 12.0 & 11.7 & 76.3 & & 6.0 & 6.4 \\
\hline 5 CAMPON & 87.0 & 83.0 & 165.0 & 628.0 & 44.0 & 19.0 & 137.5 & 7.2 & 10.6 & 82.2 & 2.3 & 16.0 & 11.5 \\
\hline 6 CAPOC & 78.0 & 66.0 & 196.0 & 512.0 & 30.0 & 20.0 & 161.0 & 9.2 & 8.2 & 82.6 & & 1.0 & 9.0 \\
\hline 7 CHATO DE ICA & 82.0 & 66.5 & 151.0 & 291.0 & 43.0 & 21.5 & 82.0 & 12.5 & 10.3 & 77.2 & 1.0 & 8.5 & 6.2 \\
\hline 8 CHIRIM & 71.0 & 58.5 & 75.0 & 174.0 & 44.5 & 18.5 & 58.0 & 12.1 & 15.8 & 72.1 & 2.6 & 17.0 & 5.9 \\
\hline 9 COLOM & 1.0 & 54.5 & 109.0 & 200.0 & 33.0 & 17.0 & 90.5 & 14.3 & 13.7 & 72.0 & & .0 & 5.1 \\
\hline 10 DAVIS H & 94.5 & 87.0 & 124.0 & 569.0 & 45.0 & 20.5 & 98.0 & 7.7 & 10.7 & 81.6 & 1.0 & 16.0 & 10.6 \\
\hline $11 \mathrm{EDV}$ & 92.5 & 90.5 & 127.0 & 599.0 & 45.5 & 21.0 & 107.5 & 6.3 & 15.3 & 78.4 & 2.3 & 18.0 & 12.5 \\
\hline$\Gamma$ & 3.0 & 72.0 & 3.0 & 296.0 & .5 & 25.5 & 76.5 & 14.5 & 10.8 & 74.7 & & .5 & 5.1 \\
\hline $13 \mathrm{~F}$ & 91.0 & 78.5 & 113.0 & 428.0 & 39.0 & 20.5 & 86.0 & 9.2 & 17.6 & 73.2 & 2 . & 20.5 & 7.9 \\
\hline $4 \mathrm{FA}$ & 85.5 & 78.5 & 104.0 & 376.0 & 39.5 & 19.5 & 77.5 & 8.9 & 17.7 & 73.4 & 3.9 & 16.5 & 8.2 \\
\hline $\mathrm{IN}$ & 7.0 & 76.5 & 106.0 & 439.0 & 36.5 & 19.5 & 83.0 & 6.9 & 10.3 & 82.8 & & 5.0 & 11.9 \\
\hline $16 \mathrm{G}$ & 116.0 & 100.5 & 139.0 & 879.0 & 44.5 & 25.0 & 96.0 & 5.3 & 21.0 & 73.7 & 4.9 & 15.0 & 13.7 \\
\hline $7 \mathrm{GL}$ & 3.0 & 64.0 & 108.0 & 263.0 & 35.0 & 20.0 & 86.0 & 9.8 & 12.5 & 77.7 & 1. & 17.0 & 7.8 \\
\hline $\mathrm{EN}$ & 7.0 & 73.0 & 99.0 & 322.0 & 39.0 & 19.5 & 81.0 & 10.9 & 17.5 & 71.6 & & 1.8 & 6.6 \\
\hline $19 \mathrm{HA}$ & 85.0 & 76.5 & 127.0 & 475.0 & 37.0 & 19.5 & 102.5 & 6.6 & 9.4 & 84.0 & 1.0 & 15.8 & 12.7 \\
\hline $20 \mathrm{HA}$ & 106.0 & 89.0 & 137.0 & 681.0 & 47.5 & 22.5 & 95.0 & 7.7 & 9.5 & 82.8 & & 17.5 & 10.7 \\
\hline I IRV & 75.0 & 69.5 & 106.0 & 298.0 & 34.5 & 18.0 & 80.0 & 7.7 & 8.7 & 83.6 & 11 & 15.5 & 10.8 \\
\hline $\mathrm{J}$ & 106.5 & 101.0 & 21.0 & 688.0 & 45.5 & 22.5 & 80.0 & 4.8 & 11.6 & 83.6 & 4. & 16.3 & 17.4 \\
\hline$E$ & 78.0 & 61.0 & 02.0 & 261.0 & 41.5 & 20.0 & 82.5 & 8.8 & 16.7 & 74.5 & & 2.0 & 8.4 \\
\hline $\mathrm{T}$ & 99.0 & 91.0 & 118.0 & 625.0 & 36.5 & 20.5 & 80.5 & 7.0 & 10.8 & 82.2 & 2.6 & 8.8 & 11.6 \\
\hline $5 \mathrm{KH}$ & 105.5 & 90.5 & 132.0 & 663.0 & 44.5 & 24.0 & 98.0 & 8.1 & 17.9 & 74.0 & & 15.0 & 9.2 \\
\hline $6 \mathrm{LH}$ & 7.5 & 62.5 & 103.0 & 254.0 & 37.0 & 23.0 & 81.5 & 13.4 & 9.8 & 76.8 & 2.2 & 0.5 & 5.7 \\
\hline $\mathrm{N}$ & .5 & 65.5 & 96.0 & 323.0 & 39.5 & 18.5 & 79.5 & 9.4 & 15.2 & 75.4 & & .0 & 7.9 \\
\hline $\mathrm{N}$ & & .0 & 108.0 & 370.0 & 37.0 & 20.5 & 87.0 & 10.0 & 16.0 & 74.0 & 2.3 & 9.0 & 7.4 \\
\hline ONO & .5 & 52.5 & 86.0 & 155.0 & 33.5 & 19.5 & 68.0 & 15.8 & 14.5 & 69.7 & - & 8.8 & 4.4 \\
\hline $\mathrm{F}$ & & 57.0 & 86.0 & 183.0 & 38.0 & 21.5 & 650 & 16.2 & 12.3 & 71.5 & - & 20.5 & 4.4 \\
\hline $31 \mathrm{PH}$ & & 70.0 & 102.0 & 298.0 & 46.5 & 23.0 & 76.0 & 13.9 & 16.4 & 69.7 & 3.1 & 16.3 & 5.0 \\
\hline$A D O D F$ ICA & 2.5 & 71.0 & 98.0 & 322.0 & 47.0 & 21.5 & 75.0 & 9.8 & 9.9 & 80.3 & 1.0 & 6.0 & 8.2 \\
\hline $33 \mathrm{~S}$ & & 68.0 & 82.0 & 240.0 & 39.0 & 22.0 & 61.0 & 12.3 & 11.5 & 76.2 & 3. & 17.5 & 6.2 \\
\hline $4 \mathrm{SA}$ & 59.5 & & 92.0 & 167.0 & 35.0 & 19.0 & 73.0 & 18.3 & 17.3 & 64.4 & 2.4 & 20.5 & 3.5 \\
\hline & 70.0 & 62.5 & 88.0 & 209.0 & 39.5 & 18.5 & 69.5 & 14.1 & 13.4 & 72.5 & 3.2 & 6.5 & 5.1 \\
\hline & & 84.5 & 152.0 & 670.0 & 46.5 & 20.0 & 124.0 & 7.2 & 10.5 & 82.3 & & 16.5 & 11.4 \\
\hline $37 \mathrm{SL}$ & & 57.5 & 97.0 & 198.0 & 33.5 & 19.5 & 75.0 & 10.1 & 9.3 & 80.6 & 3.8 & 16.3 & 7.9 \\
\hline 38 TOLBERT & 84.0 & 80.0 & 87.0 & 333.0 & 41.0 & 22.0 & 60.0 & 9.0 & 9.3 & 81.7 & 3.0 & 15.0 & 8.7 \\
\hline 39 TOMMY ATKINS & 95.0 & 86.0 & 118.0 & 510.0 & 46.5 & 19.0 & 91.0 & 7.7 & 7.5 & 84.8 & 2.6 & 15.8 & 10.9 \\
\hline 40 ZILL & 79.5 & 64.5 & 88.0 & 239.0 & 36.5 & 19.0 & 64.0 & 10.0 & 13.8 & 76.2 & 3.0 & 17.0 & 7.6 \\
\hline Mean & 82.1 & 72.0 & 110.0 & 375.0 & 39.8 & 20.4 & 84.2 & 10.1 & 12.9 & 77.0 & 2.5 & 17.6 & 8.4 \\
\hline & & & 25.4 & 186.5 & 5.0 & 2.1 & 20.9 & 3.1 & 3.3 & 4.9 & 1.4 & 2.0 & 3.0 \\
\hline Coefficient of variation $(\%)$ & 15.9 & 18.3 & 23.1 & 49.7 & 12.6 & 10.5 & 24.8 & 31.0 & 25.5 & 6.3 & 54.2 & 11.4 & 35.3 \\
\hline
\end{tabular}


Table 2. Correlation analysis of 12 quantitative fruit variables of 40 mango varieties.

\begin{tabular}{|c|c|c|c|c|c|c|c|c|c|c|c|c|}
\hline & FW & SW & FT & ST & ${ }^{\circ}$ Brix & Text & FL & LS & $\% \mathrm{PFs}$ & $\mathrm{FW}$ & $\% \mathrm{Se}$ & $\% \mathrm{Pp}$ \\
\hline FW & 1 & & & & & & & & & & & \\
\hline SW & $0.62^{* *}$ & 1 & & & & & & & & & & \\
\hline FT & $0.95^{* *}$ & $0.59^{* *}$ & 1 & & & & & & & & & \\
\hline ST & $0.53^{* *}$ & $0.42^{* *}$ & $0.47^{* *}$ & 1 & & & & & & & & \\
\hline${ }^{\circ}$ Brix & $-0.39^{*}$ & $-0.39^{*}$ & $-0.50^{* *}$ & -0.22 & 1 & & & & & & & \\
\hline Text & $0.34^{*}$ & 0.15 & $0.37^{*}$ & 0.17 & $-0.36^{*}$ & 1 & & & & & & \\
\hline FL & $0.51^{* *}$ & 0.14 & $0.49^{* *}$ & 0.14 & -0.02 & 0.08 & 1 & & & & & \\
\hline LS & $0.35^{*}$ & 0.03 & $0.37^{*}$ & -0.02 & 0.03 & 0.05 & $0.93^{* *}$ & 1 & & & & \\
\hline$\% \mathrm{PFs}$ & $0.81^{* *}$ & $0.39^{*}$ & $0.78^{* *}$ & $0.44^{* *}$ & -0.287 & $0.43^{* *}$ & $0.47^{* *}$ & $0.38^{*}$ & 1 & & & \\
\hline FW & $0.93^{* *}$ & $0.48^{* *}$ & $0.93^{* *}$ & $0.40^{*}$ & $-0.36^{*}$ & 0.31 & $0.71^{* *}$ & $0.62^{* *}$ & $0.83^{* *}$ & 1 & & \\
\hline$\% \mathrm{Se}$ & $0.73^{* *}$ & $0.49^{* *}$ & $0.72^{* *}$ & $0.53^{* *}$ & -0.23 & 0.24 & $0.71^{* *}$ & $0.62^{* *}$ & $0.64^{* *}$ & $0.80^{* *}$ & 1 & \\
\hline$\% \mathrm{Pp}$ & $0.91^{* *}$ & $0.47^{* *}$ & $0.92^{* *}$ & $0.35^{*}$ & $-0.36^{*}$ & 0.27 & $0.72^{* *}$ & $0.63^{* *}$ & $0.76^{* *}$ & $0.99^{* *}$ & $0.77^{* *}$ & 1 \\
\hline
\end{tabular}

** The correlation is significant at the 0.01 level. * The correlation is significant at the 0.05 level. Fruit width (FW), seed width (SW), fruit thickness (FT), seed thickness (ST), Brix degrees ( ${ }^{\circ}$ Brix), texture (Text), fruit length (FL), seed length (LS), fresh skin percentage $(\% \mathrm{PFs})$, fruit weight $(\mathrm{Fw})$, seed percentage $(\% \mathrm{Se})$ and pulp percentage $(\% \mathrm{Pp})$.

\section{Grouping of forty mango varieties according to quantitative variables.}

The PCA results of the thirteen quantitative variables indicated that the total variance explained with the first, second, third and fourth components was $84.3 \%$. The first component accounted for about $47.97 \%$ of the total variability, the second for an additional $16.69 \%$, while the third and fourth components accounted for $11.19 \%$ and $8.44 \%$ of the variability, respectively. The first component included five variables, which illustrated high or moderate values in fruit width, fruit thickness, fruit weight, seed percentage, and pulp/seed ratio.

On the other hand, the dendrogram generated distinguishes three groups at a distance of approximately $20 \%$, the calculated coefficient of cophenetic correlation was 0.72 which indicated a poor hierarchical structure. However, when observing in Figure 2, it is notable that the grouping obtained is mainly due to the size and weight of the fruit, so that the first group was formed by 13 mango varieties, which are distinguished mostly by being smaller in size and weight. The second group was made up of 14 varieties which have medium sizes, and the third group was conformed of 13 mango varieties, of which the main characteristics were their greater weight and size. In Peru, Banco Agrario (2007), also made a classification of three groups of mango varieties, but, according to the epicarps color, where red varieties are also larger, and this coincides with the dendrogram obtained. In this Group I, represented by smaller varieties are mostly of green epicarp. Mango fruit varieted constituted Group III with red epicarp and larger in size than Group I and II. Considering the ripening period in the subtropical zone of Argentina, Fernandez et al. (2001) classify mango varieties as very early; ripe fruits in the first half of December; early; ripe fruits towards the end of December and beginning of January; medium; ripe fruits from the second half of January to the end of February; late; ripe fruits from the end of February to the end of March; very late; mid-March to the end of April.

Table 3 shows the averages of the fruit quantitative variables evaluated in the 40 mango varieties according to the groups formed. Group I, is characterized by lower average values for the variables fruit weight (FW; 252.5 $\mathrm{g})$, fruit length (FL; $102.3 \mathrm{~mm})$, seed percentage (\% Se; 12.1), fresh skin percentage (\% FPs; 14.2), pulp percentage (\% Pp; 73.6) and texture (Text; $1.7 \mathrm{~kg} /$ $\mathrm{cm}^{2}$ ), while the ${ }^{\circ}$ Brix value was higher and statistically significant. Therefore, in Group I, we cand find the sweeter varieties, although the average pulp/seed ratio was not ideal (pulp/se $=6.5)$. In contrast, Group III showed higher values of the above-mentioned variables, except ${ }^{\circ}$ Brix. Although the large sizes and weights do not represent quality or competitiveness in the market, the knowledge and understanding of these values will allow better use and management of the different mango varieties. In addition, complementary studies on the nutritional diversity of the varieties would expand the market potential, allowing its use both for consumption as fresh fruit and in industrialized form. It is also necessary to evaluate the correlation between quantitative variables and the ripening period, which will ensure the public consumer's satisfaction. From this research it is also expected to initiate studies on the industrialization and commercialization of products derived from the identified promising varieties, as well as the conservation and packaging, nutritional characterization, and management techniques during the harvesting period, considering the environmental characteristics of the harvesting and agroindustrial transformation area. 


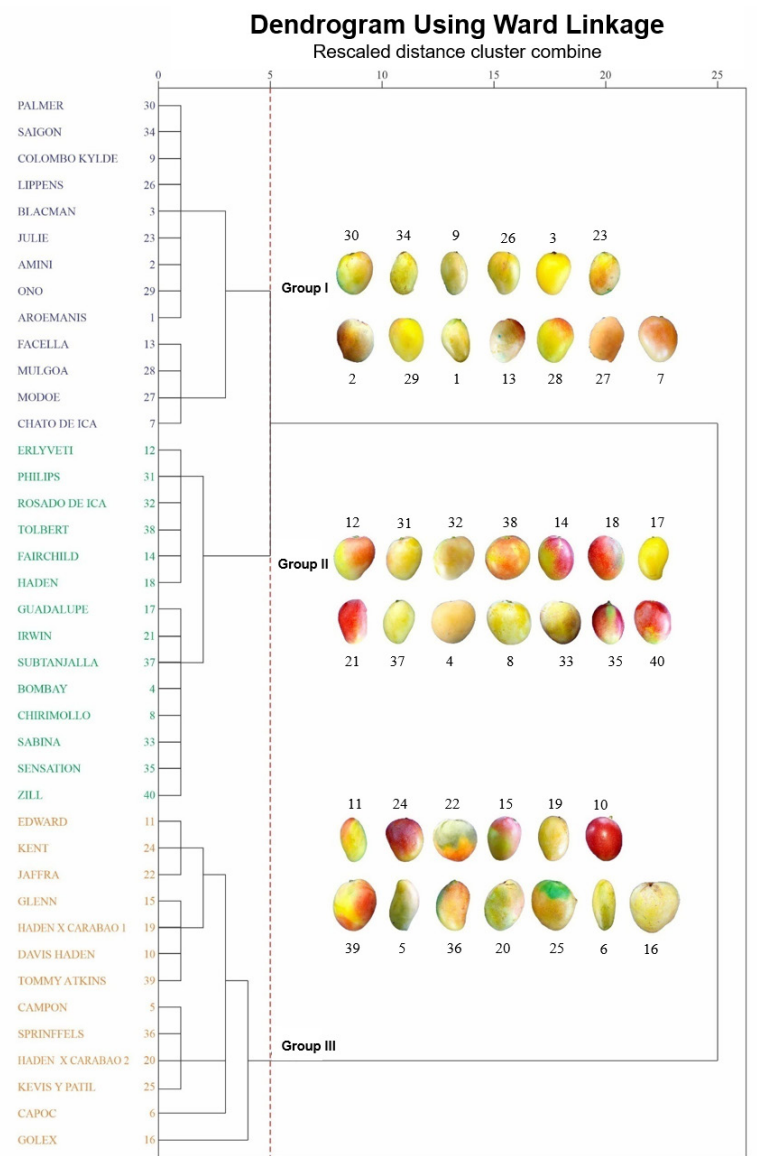

Figure 2. Dendrogram generated from the similarity between the 40 mango varieties present in the germplasm bank of the EEA El Chira, Piura, Peru. The image of each fruit is placed in the order of the dendrogram from left to right, from top to bottom indicated by the number corresponding to the variety.

Table 3. Average of the main characteristics of mango varieties according to groupings.

\begin{tabular}{cccccccccccccc}
\hline GROUPS & $\begin{array}{c}\text { FW } \\
(\mathrm{mm})\end{array}$ & $\begin{array}{c}\text { FT } \\
(\mathrm{mm})\end{array}$ & $\begin{array}{c}\text { FL } \\
(\mathrm{mm})\end{array}$ & $\begin{array}{c}\text { FW } \\
(\mathrm{g})\end{array}$ & $\begin{array}{c}\text { SW } \\
(\mathrm{mm})\end{array}$ & $\begin{array}{c}\text { ST } \\
(\mathrm{mm})\end{array}$ & $\begin{array}{c}\text { SL } \\
(\mathrm{mm})\end{array}$ & $\begin{array}{c}\% \\
\text { Se }\end{array}$ & $\begin{array}{c}\% \\
\text { PFs }\end{array}$ & $\begin{array}{c}\% \\
\text { Pp }\end{array}$ & $\begin{array}{c}\text { Text } \\
\left(\mathrm{kg} / \mathrm{cm}^{2}\right)\end{array}$ & ${ }^{\circ}$ Brix & Pulp/se \\
\hline Group I $76.0 \mathrm{a}$ & $61.8 \mathrm{a}$ & $102.3 \mathrm{a}$ & $252.5 \mathrm{a}$ & $37.1 \mathrm{a}$ & $19.8 \mathrm{a}$ & $78 . \mathrm{a}$ & $12.1 \mathrm{a}$ & $14.4 \mathrm{a}$ & $73.6 \mathrm{a}$ & $1.7 \mathrm{a}$ & $19.9 \mathrm{~b}$ & $6.5 \mathrm{a}$ \\
Group II & $76.8 \mathrm{a}$ & $68.1 \mathrm{a}$ & $93.4 \mathrm{a}$ & $269.8 \mathrm{a}$ & $40.1 \mathrm{ab}$ & $20.4 \mathrm{a}$ & $71.4 \mathrm{a}$ & $11.1 \mathrm{a}$ & $12.7 \mathrm{a}$ & $76.1 \mathrm{a}$ & $3.0 \mathrm{~b}$ & $16.3 \mathrm{a}$ & $7.1 \mathrm{a}$ \\
Group III & $96.0 \mathrm{~b}$ & $86.3 \mathrm{~b}$ & $135.5 \mathrm{~b}$ & $610.6 \mathrm{~b}$ & $42.3 \mathrm{~b}$ & $21.0 \mathrm{a}$ & $104 . \mathrm{b}$ & $7.1 \mathrm{~b}$ & $11.8 \mathrm{~b}$ & $81.1 \mathrm{~b}$ & $2.8 \mathrm{ab}$ & $16.7 \mathrm{a}$ & $11.8 \mathrm{~b}$ \\
\hline
\end{tabular}

Fruit width (FW), fruit thickness (FT), fruit length (FL), fruit weight (Fw), seed width (SW), seed thickness (ST), seed length (SL), seed percentage $(\% \mathrm{Se})$, fresh skin percentage $(\% \mathrm{PFs})$, pulp percentage $(\% \mathrm{Pp})$, texture $($ Text $)$, Brix degree $\left({ }^{\circ} \mathrm{Brix}\right)$ and pulp/seed ratio $(\mathrm{Pulp} / \mathrm{se})$. Different letters next to the numbers indicate significant differences between values.

\section{Conclusion}

The results obtained in this work allowed highlighting the potential of some mango varieties, mainly due to a higher percentage of pulp, pulp/seed ratio, and ${ }^{\circ}$ Brix; proving to be an alternative for the national and international fresh fruit market, as well as for the export agroindustry through by-products based on mango pulp, preserves, chunks, and juices.

\section{Acknowledgments}

Special thanks to Ing. Ulises Vegas Rodríguez, Director of the Estación Experimental Agraria El ChiraPiura, for his contribution to the understanding of mango cultivation. We also appreciate Ing. Oswaldo Bereche Crisanto for obtaining fruit characterization data in the field and laboratory. To Mr. Santos Porras Meca for the care and integrated management of the germplasm bank and to Mr. Antony Del Aguila for the help with Figure 1.

Financially supported by the project "Mejoramiento de los Servicios de Investigación en la Caracterización de los Recursos Genéticos de la Agrobiodiversidad en 17 Departamentos del Perú (PROAGROBIO)”. Viabilizado con Código Único de Inversiones - CUI N ${ }^{\circ} 2480490$. 


\section{References}

AGRODATAPERU. Exportaciones agropecuarias del Perú 2020. Disponible en: https://www.agrodataperu. com/2021/01/mangos-frescos-peru-exportacion-2020diciembre.html. Acesso em: 8 jan. 2021.

BANCO AGRARIO. Cultivo y variedades de mango. Lima: Agrobanco, 2007. p.1-20.

CARNEIRO, M.A.; LIMA, A.M.N.; CAVALCANTE, I.H.L.; DE SOUSA, K.D.M.; OLDONI F.C.A.; BARBOSA, K.D. Production and quality of mango fruits cv. Tommy Atkins fertigated with potassium in semi-arid region. Revista Brasileira de Fruticultura, Jaboticabal, v.40, n.5, p.e-034, 2018.

CRANE, J.H.; WASIELEWSKI, J.; BALERDI, C.F.; MAGUIRE I. Mango growing in the Florida home landscape. Gainesville: University of Florida, 2017. p.1-10. Available from: https://edis.ifas.ufl.edu/mg216.

FERNÁNDEZ, V.B.; RIVADENEIRA, M.; AGUIRRE, C. Cultivares de Mango en al Area Subtropical de Salta y Jujuy. Revista de Información Sobre Investigación y Desarrollo Agropecuario, Buenos Aires, v.21, n.1, p.113-117, 2001.

IBGE. Produção agrícola municipal. Rio de Janeiro, 2018. Disponível em: http://www.sidra.ibge.gov.br.

LEDESMA, N. The genetic diversity of mangoes. In: LU, P.; SAUCO, V.G. (ed.). Achieving sustainable cultivation of mangoes. London: Burleigh Dodds Science Publishing, 2018.

MAIA, M.C.C.; ARAÚJO, L.B.; DIAS, C.T.S.; OLIVEIRA, L.C.; VASCONCELOS, L.F.L.; CARVALHO JÚNIOR, J.E.V.; SIMEÃO, M.; BASTOS, Y.G.M. Seleção de genótipos em uma população de melhoramento de manga rosa usando o método multivariado biplot. Ciência Rural, Santa Maria, v.46, n.10, p.1689-1694, 2016.

MINAGRI - Ministerio de Agricultura y Riego. El comercio exterior agrario. Lima, 2014.
MITCHAM, E.J.; MCDONALD, R.E. Cell wall modification during ripening of 'Keitt' and 'Tommy Atkins' mango fruit. Journal of the American Society for Horticultural Science, Alexandria, v.117, n.6, p.919924, 1992.

PITCHAON, M. Antioxidant capacity of extracts and fractions from mango (Mangifera indica Linn.) seed kernels. International Food Research Journal, Serdang, v.18, n.1, p.523-528, 2011.

RODRÍGUEZ-PLEGUEZUELO, C.R.; DURÁNZUAZO, V.H.; MURIEL-FERNÁNDEZ, J.L.; FRANCO TARIFA, D. Physico-chemical quality parameters of mango (Mangifera indica L.) fruits grown in a Mediterranean subtropical climate (se Spain). Journal of Agricultural Science and Technology, Teherán, v.14, n.2, p. 365-374, 2012.

SHAH, K.; PATEL, M.; PATEL, R.; PARMAR, P. Mangifera indica (Mango). Pharmacognosy Reviews, Bangalore, v.4, n.7, 42-48, 2010.

SIEA - Sistema Integrado de Estadística Agraria. Calendário de siembras y cosechas. Lima: Ministerio de Agricultura y Riego del Perú, 2014-2019. Disponible en: http://siea.minagri.gob.pe/portal/calendario/.

SILLER-CEPEDA, J.; MUY-RANGEL, D.; BÁEZSAÑUDO, M.; ARAIZA-LIZARDE, E.; IRETAOJEDA, A. Calidad pos cosecha de cultivares de mango de maduración temprana, intermedia y tardía. Revista Fitotecnia Mexicana, Chapingo, v.32, n.1, p.45-52, 2009.

SOWMIYA, S.; SOUNDARAPANDIAN, P.; RAJAN, $\mathrm{S}$. Bioactive studies of Mangifera indica aganist bacteria isolated fromurine samples. Current Research Journal of Biological Sciences, Tamil Nadu, v.1, n.3, p.139-143, 2009.

STATGRAPHICS. StatGraphics centurion XVIII. Versión 18. Madrid. 2009. Available from: http://www. statgraphics.net/descargas/. 